\title{
Neurogliaform and Ivy cells: a major family of nNOS expressing GABAergic neurons
}

\section{Caren Armstrong *, Esther Krook-Magnuson and Ivan Soltesz}

Department of Anatomy and Neurobiology, University of California Irvine, Irvine, CA, USA

Edited by:

Ludovic Tricoire, Université Pierre et Marie Curie, France

\section{Reviewed by:}

Gianmaria Maccaferri, Northwestern

University, USA

Thomas Klausberger, MRC University of Oxford, UK

Linda Overstreet-Wadiche, University of Alabama Birmingham, USA

Marco Capogna, Medical Research Council, UK

${ }^{*}$ Correspondence:

Caren Armstrong, Department of Anatomy and Neurobiology,

University of California, 192 Irvine Hall, Irvine, CA 92697-1280, USA.

e-mail: cmarmstr@uci.edu
Neurogliaform and Ivy cells are members of an abundant family of neuronal nitric oxide synthase (nNOS) expressing GABAergic interneurons found in diverse brain regions. These cells have a defining dense local axonal plexus, and display unique synaptic properties including a biphasic postsynaptic response with both a slow $\mathrm{GABA}_{A}$ component and a $\mathrm{GABA}_{\mathrm{B}}$ component following even a single action potential. The type of transmission displayed by these cells has been termed "volume transmission," distinct from both tonic and classical synaptic transmission. Electrical connections are also notable in that, unlike other GABAergic cell types, neurogliaform family cells will form gap junctions not only with other neurogliaform cells, but also with non-neurogliaform family GABAergic cells. In this review, we focus on neurogliaform and Ivy cells throughout the hippocampal formation, where recent studies highlight their role in feedforward inhibition, uncover their ability to display a phenomenon called persistent firing, and reveal their modulation by opioids. The unique properties of this family of cells, their abundance, rich connectivity, and modulation by clinically relevant drugs make them an attractive target for future studies in vivo during different behavioral and pharmacological conditions.

Keywords: feedforward inhibition, persistent firing, opioid, $G A B A_{B}, G A B A_{A, \text { slow }}$

\section{INTRODUCTION}

The neurogliaform family of cells is one of the major groups of GABAergic neurons expressing nitric oxide synthase (nNOS). Neurogliaform cells, originally described by Cajal as arachniform cells (Ramón y Cajal, 1922; Ramón y Cajal, 1999), together with the closely related Ivy cells, which were only recently characterized (Fuentealba et al., 2008), are estimated to be the most abundant GABAergic cell type in area CA1 of the hippocampus (Fuentealba et al., 2008). However, the neurogliaform family of cells is found in large numbers not only throughout CA1, but also across a range of brain regions, including the entire hippocampal formation (Vida et al., 1998; Price et al., 2005; Elfant et al., 2008; Price et al., 2008; Karayannis et al., 2010; Szabadics et al., 2010; Armstrong et al., 2011; Krook-Magnuson et al., 2011; Markwardt et al., 2011), the neocortex (Tamas et al., 2003; Simon et al., 2005; Olah et al., 2007; Szabadics et al., 2007; Olah et al., 2009), the piriform cortex (Suzuki and Bekkers, 2012), striatum (Ibanez-Sandoval et al., 2011), and the habenula of the thalamus (Weiss and Veh, 2011). Thus, these cells are not only abundant, but also widespread. Yet their function in the context of local circuit dynamics is only beginning to be unraveled.

Here, in addition to reviewing the known anatomical, synaptic, neuromodulatory, and connective properties of neurogliaform family cells, we discuss their potential network functions, particularly in the hippocampal formation.

\section{UNIQUE AXONS, UNIQUE CONNECTIONS}

Despite their wide distribution, cells within the neurogliaform family have very similar characteristics across brain regions, and these unique characteristics clearly set them apart from other
GABAergic cell types. Neurogliaform cells have a dense local axonal plexus and generally small, round, somata (Figure 1). The axons of neurogliaform cells have frequent, small en passant boutons, which despite their small size can form synaptic contacts (Vida et al., 1998; Fuentealba et al., 2008; Olah et al., 2009). The synapses formed by neurogliaform family cell boutons, however, do not necessarily form classical synapses like those of other GABAergic cell classes, in that the synaptic cleft at identified synapses is unusually wide and some boutons, complete with synaptic vesicles, do not have an easily identifiable postsynaptic target in the classical sense (Vida et al., 1998; Olah et al., 2009). Their unique synaptic and axonal morphologies underlie some key features of neurogliaform synaptic transmission (Figure 2), namely (1) the ability of neurogliaform cells to mediate GABAergic volume transmission, affecting virtually any processes within their dense axonal plexus, (2) the production of a slow $\mathrm{GABA}_{\mathrm{A}}$ current in the postsynaptic cell $\left(\mathrm{GABA}_{\mathrm{A}, \mathrm{slow}}\right)$, and (3) the postsynaptic $G_{A B A}$ response to even a single neurogliaform action potential (Tamas et al., 2003; Price et al., 2005; Szabadics et al., 2007; Price et al., 2008; Olah et al., 2009; Karayannis et al., 2010; Capogna and Pearce, 2011).

Neurogliaform cells' ability to induce a biphasic current in the postsynaptic cell, including both a $\mathrm{GABA}_{\mathrm{A}}$-mediated and a $\mathrm{GABA}_{\mathrm{B}}$-mediated component, is a property which has been consistently observed across brain regions (Tamas et al., 2003; Price et al., 2005; Olah et al., 2007; Szabadics et al., 2007; Armstrong et al., 2011). The $G_{A B A}$ and $G A B A_{B}$-mediated components can be separated based on reversal potential, since the $\mathrm{K}^{+}$-mediated $\mathrm{GABA}_{B}$ component and the largely $\mathrm{Cl}^{-}$-mediated $\mathrm{GABA}_{\mathrm{A}}$ component reverse at different membrane potentials. Additionally, the $\mathrm{GABA}_{\mathrm{A}}$ 


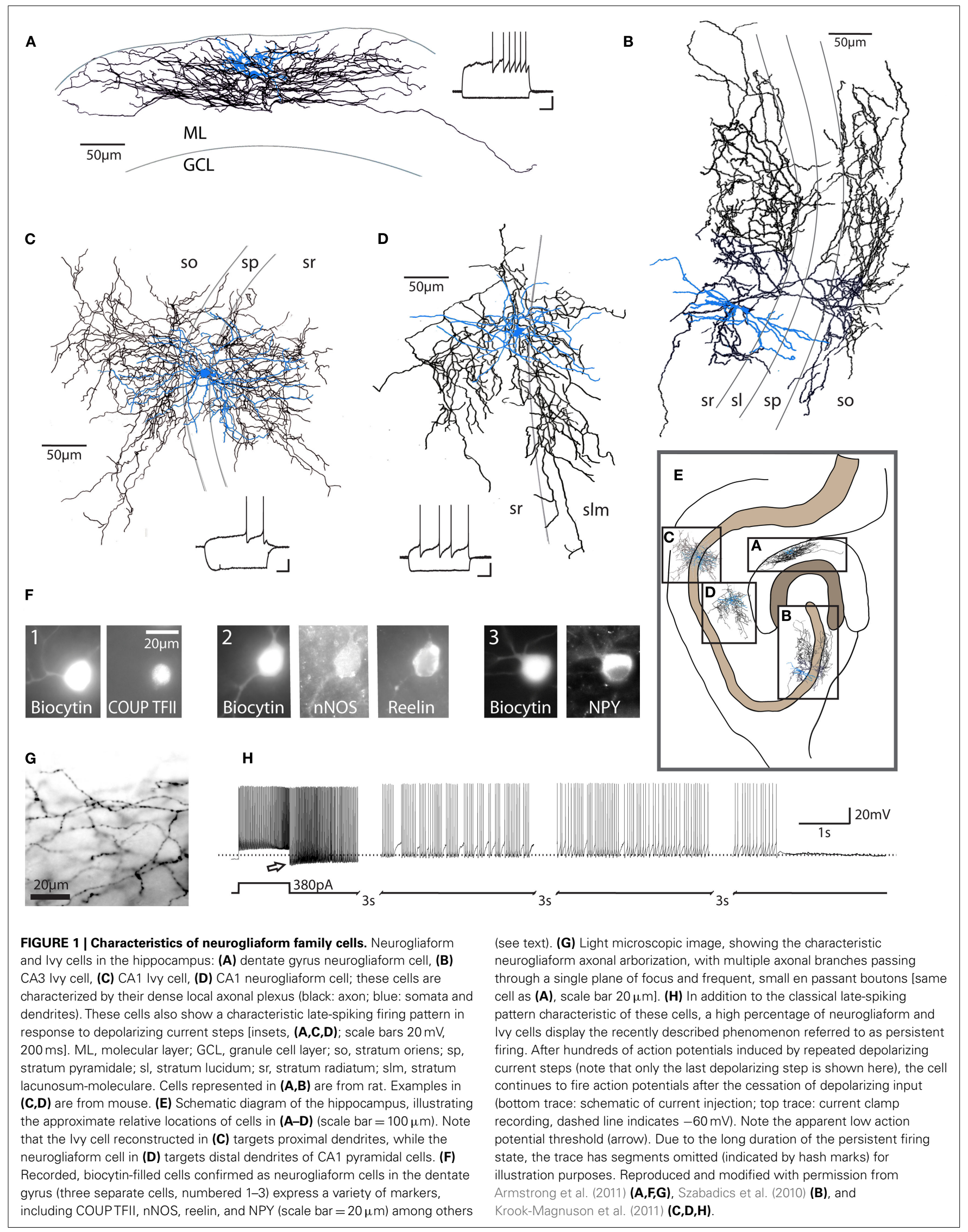



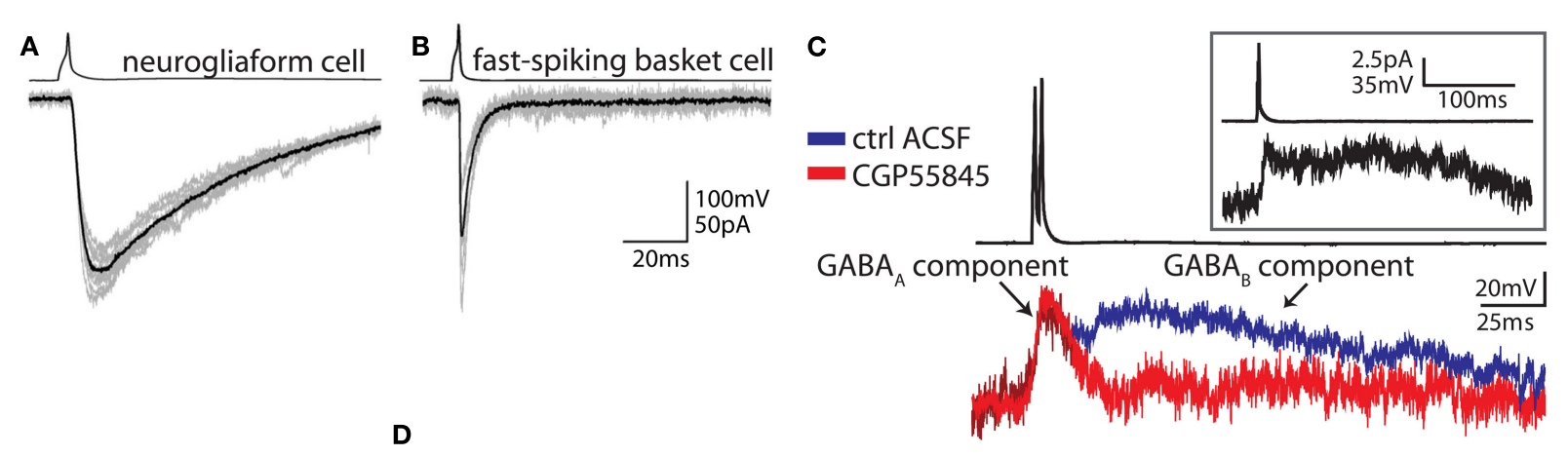

D
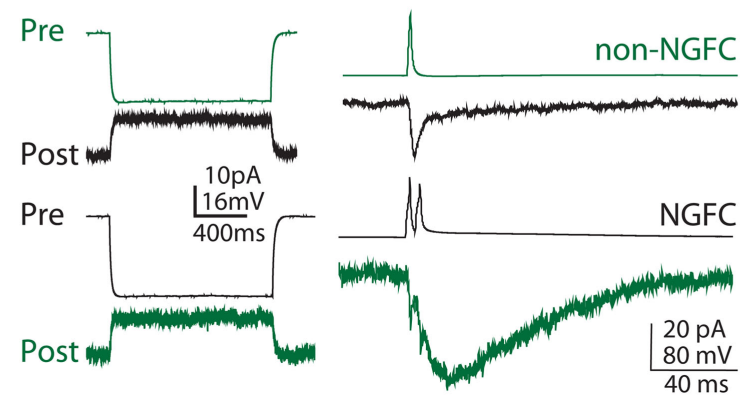

FIGURE 2 | Unique synaptic properties of neurogliaform cells. (A) Action potentials in a neurogliaform cell (top trace, example from neocortex)

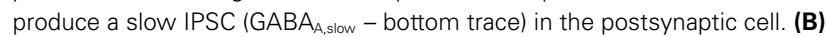
In contrast, action potentials in fast-spiking basket cell (top trace) produce an IPSC with fast kinetics in the postsynaptic cell (bottom trace). (C) Neurogliaform cells (averaged examples from dentate gyrus) produce a biphasic postsynaptic response, consisting of a slow $G_{A B A}$ and a GABA component, which can be distinguished by application of the $G_{A B A_{B}}$ antagonist CGP55845 (red trace). This biphasic response can be seen following even a single presynaptic action potential (inset). (D)

Neurogliaform cells (NGFC, black traces) can form both electrical and chemical synaptic connections with other GABAergic cell types. In this example, an electrical and unidirectional synaptic connection between a
NGFC (black traces) and a non-NGFC (green traces) can be appreciated (example from dentate gyrus). Left traces: a hyperpolarizing current step (Pre, current clamp responses shown in the upper traces of each example), evokes an outward current in the electrically connected cell (Post, voltage clamp responses shown in the lower traces of each example). Right: When an action potential is evoked in the presynaptic non-NGFC, only a short inward current, due to electrical coupling, is observed in the connected NGFC, while both electrical and chemical synaptic responses can be appreciated in the postsynaptic non-NGFC in response to NGFC stimulation (upper traces, both pre and postsynaptic traces are averaged). Note the electrical responses in the non-NGFC riding on top of the slow GABA-mediated IPSC. Reproduced and modified with permission from Szabadics et al. (2007) (A,B) and Armstrong et al. (2011) (C,D). and $\mathrm{GABA}_{\mathrm{B}}$-mediated components can be pharmacologically separated using specific antagonists for $\mathrm{GABA}_{\mathrm{A}}$ and $\mathrm{GABA}_{\mathrm{B}}$ receptors (Figure 2). Importantly, this biphasic GABA-mediated current results in a large inhibitory charge transfer in the postsynaptic target, and involves even traditionally extrasynaptic receptors, such as $\delta$ subunit-containing $\mathrm{GABA}_{\mathrm{A}}$ receptors and $\mathrm{GABA}_{\mathrm{B}}$ receptors, as well as classically synaptic receptors, e.g., benzodiazepine-sensitive $\gamma$ subunit-containing $\mathrm{GABA}_{\mathrm{A}}$ receptors (Szabadics et al., 2007; Olah et al., 2009; Karayannis et al., 2010).

The kinetics of the neurogliaform cell-evoked $\mathrm{GABA}_{\mathrm{A}}$ response are also considerably slower than the kinetics of responses to other GABAergic cell types, and these events, referred to as $\mathrm{GABA}_{\mathrm{A} \text {,slow }}$ (Pearce, 1993; reviewed in Capogna and Pearce, 2011), were shown to arise from neurogliaform cells (Tamas et al., 2003; Price et al., 2005; Szabadics et al., 2007). In theory, $\mathrm{GABA}_{\mathrm{A} \text {,slow }}$ could be due to multiple, asynchronous, vesicular release. However, the kinetics of the $\mathrm{GABA}_{\mathrm{A} \text {,slow }}$ response are not affected by altering release probability through variation of external $\mathrm{Ca}^{2+}$ concentration, such that vesicular release properties cannot explain the kinetics (Szabadics et al., 2007). Dendritic filtering of neurogliaform cell input to distal dendrites also cannot explain the slow kinetics, since other dendritically targeting cells (in this case, Martinotti cells) do not induce $\mathrm{GABA}_{\mathrm{A} \text {,slow }}$ (Szabadics et al., 2007). Further, while spillover of GABA does occur, affecting both $\mathrm{GABA}_{\mathrm{A} \text {,slow }}$ and $\mathrm{GABA}_{\mathrm{B}}$ mediated events, the extreme kinetics of the responses are not fully explained by GABA spillover. Importantly, the postsynaptic $\mathrm{GABA}_{\mathrm{A} \text {,slow }}$ response is highly sensitive to low-affinity competitive $\mathrm{GABA}_{\mathrm{A}}$ receptor antagonists, indicating that low concentrations of GABA at the postsynaptic membrane contribute to the slow unitary kinetics of neurogliaform cell connections (Szabadics et al., 2007). These data suggest that the nature of the GABA transient (the spatiotemporal concentration profile of GABA at the synapse) is largely responsible for the kinetics of neurogliaform connections (Krook-Magnuson and Huntsman, 2007; Szabadics et al., 2007; Karayannis et al., 2010). In turn, this unique GABA transient can be explained by the morphology of the synapse (i.e., the relatively small area combined with the relatively large distances between pre- and post-synaptic processes; Szabadics et al., 2007; Olah et al., 2009). Interestingly, although in vivo neurogliaform cells do fire in a phase-locked manner with theta rhythms (Fuentealba et al., 2010), paired neurogliaform cell connections in acute slices demonstrate profound depression with repeated 
stimulation (Tamas et al., 2003), an effect which persists in the presence of $\mathrm{GABA}_{\mathrm{B}}$ antagonists (Karayannis et al., 2010).

The axonal arbors of neurogliaform cells described above are one of the most distinctive features of these cells. While the axons of neurogliaform cells form a unique dense, local plexus, they can also cross boundaries of brain regions. For example, neurogliaform cells were recently identified in the molecular layer of the dentate gyrus (Armstrong et al., 2011), where importantly, it was found that their axons can cross the hippocampal fissure and extend into the adjacent CA1 or subiculum (Armstrong et al., 2011). Similarly, axons of neurogliaform cells in the CA1 can cross into dentate molecular layer (Ceranik et al., 1997; Price et al., 2005; Fuentealba et al., 2010). This extension of axons across boundaries is a notable feature among GABAergic cells, suggesting that neurogliaform cells may serve to share information between, and coordinate the activities of, distinct brain regions.

Beyond their remarkable chemical synapses, neurogliaform cells are also unusual with regard to their electrical synapses. Interneurons typically form gap junctions preferentially with members of the same cell type. In contrast, neurogliaform cells frequently form gap junctions with a wide variety of other GABAergic cell types (Figure 2; Simon et al., 2005; Zsiros and Maccaferri, 2005; Olah et al., 2007; Zsiros and Maccaferri, 2008; Armstrong et al., 2011). This is important when considering the role of neurogliaform cells in hippocampal networks, which will be discussed below.

\section{DIVERSITY AND DIVISIONS}

Despite the similarities in axonal and synaptic properties of individual cells of the neurogliaform family, there are some notable differences between them as well. Members of the neurogliaform family may differ in where they reside within a given brain region, the input they receive, and the domain of the postsynaptic cells their axons target, as well as in the neuronal markers that they express.

As mentioned above, the neurogliaform family of cells is composed of neurogliaform cells and Ivy cells. Neurogliaform cells classically target the distal dendrites of principal cells while Ivy cells, which have to date been definitively identified in the CA1 and the CA3 of the hippocampus (Fuentealba et al., 2008; Szabadics and Soltesz, 2009; Szabadics et al., 2010), have a unique position in and around the pyramidal cell layer, where they may have different incoming and outgoing connectivity when compared to neurogliaform cells. In the CA1, where Ivy cells were first described (Fuentealba et al., 2008), neurogliaform cells in and near the stratum lacunosum-moleculare receive excitatory inputs from both the temporo-ammonic pathway and CA3 Schaffer collaterals, and in turn target the distal dendrites of CA1 pyramidal cells (Figures 1 and 3; Price et al., 2005; Fuentealba et al., 2010). In contrast, Ivy cells reside in or near the stratum pyramidale, receive excitatory input from local pyramidal cells as well as presumably from CA3 Schaffer collaterals, and target the proximal dendrites of CA1 pyramidal cells (Fuentealba et al., 2008). This differential input means that, while neurogliaform cells near the CA1 lacunosummoleculare serve a primarily feedforward inhibitory role, Ivy cells near the pyramidale are poised to mediate both feedforward and feedback inhibition to CA1 pyramidal cells. Ivy and neurogliaform cells can also differ in their in vivo firing properties and dendritic morphologies (Fuentealba et al., 2008; Fuentealba et al., 2010), and differences in network functions of neurogliaform and Ivy cells in vivo will be discussed further below.

Even within the different types of neurogliaform family cells, there are differences in neuronal markers that can be used for identification. Thus, while neuropeptide Y (NPY), nNOS, COUP TFII, $\alpha$-actinin, $\mathrm{GABA}_{\mathrm{A}} \alpha_{1}, \mathrm{GABA}_{\mathrm{A}} \delta$, and reelin are notably found in neurogliaform cells (Figure 1), there is significant heterogeneity in marker expression from cell to cell such that no one marker or combination of markers captures, uniquely, all neurogliaform cells (Deller and Leranth, 1990; Ratzliff and Soltesz, 2001; Price et al., 2005; Simon et al., 2005; Fuentealba et al., 2008; Karagiannis et al., 2009; Olah et al., 2009; Fuentealba et al., 2010; Tricoire et al., 2010). Ivy cells of the CA1 seem to share many of the same markers as neurogliaform cells, but have not been observed to express reelin (Fuentealba et al., 2010). Interestingly, the presence or absence of nNOS may serve as a marker of developmental origin for both neurogliaform and Ivy cells, that is whether the cells arise from the medial or caudal ganglionic eminences, both of which can generate neurogliaform family cells (Tricoire et al., 2010).

\section{ELECTROPHYSIOLOGICAL PROPERTIES OF NEUROGLIAFORM FAMILY CELLS}

As might be expected due to their differential inputs and placement within the CA1, Ivy and neurogliaform cells of the CA1 differ also in their in vivo firing patterns. In anesthetized animals, when both theta and gamma oscillations are recorded from the stratum pyramidale, individual Ivy cells fire at a low frequency shortly after the trough of theta - that is, after CA 3 input and just after CA1 pyramidal cells fire - and during the trough of gamma oscillations, while staying primarily silent during ripples (Fuentealba et al., 2008; Klausberger and Somogyi, 2008; Mizuseki et al., 2009; Fuentealba et al., 2010). On the other hand, neurogliaform cells fire just after the peak of theta, following input to CA1 from the entorhinal cortex; are phase-coupled with the locally recorded gamma; and are either unmodulated by, or show a decrease in firing during ripples (Buzsaki, 2002; Fuentealba et al., 2010). In awake animals, putative Ivy cells recorded using tetrodes have similar firing properties during theta oscillations and ripples as Ivy cells in anaesthetized animals (Fuentealba et al., 2008).

Despite these differences in firing patterns in vivo, when recordings are made from slices in whole-cell patch configuration, both Ivy and neurogliaform cells exhibit a characteristic late-spiking firing pattern, often with a depolarizing ramp and subthreshold oscillations in the gamma frequency range leading up to the first spikes (Szabadics et al., 2007; Armstrong et al., 2011; KrookMagnuson et al., 2011; Weiss and Veh, 2011; Figure 1). While neurogliaform cells of rodents typically do not exhibit a sag upon hyperpolarization, neurogliaform cells of humans and monkeys do (Olah et al., 2007; Povysheva et al., 2007).

Both Ivy and neurogliaform cells exhibit the recently described phenomenon of persistent firing (Krook-Magnuson et al., 2011; Figure 1). Persistent firing is a state of continued firing in the absence of continued input (Sheffield et al., 2011). Experimentally, it is induced by repeated somatic current injections, causing the cell to fire hundreds of action potentials over the span of minutes. 


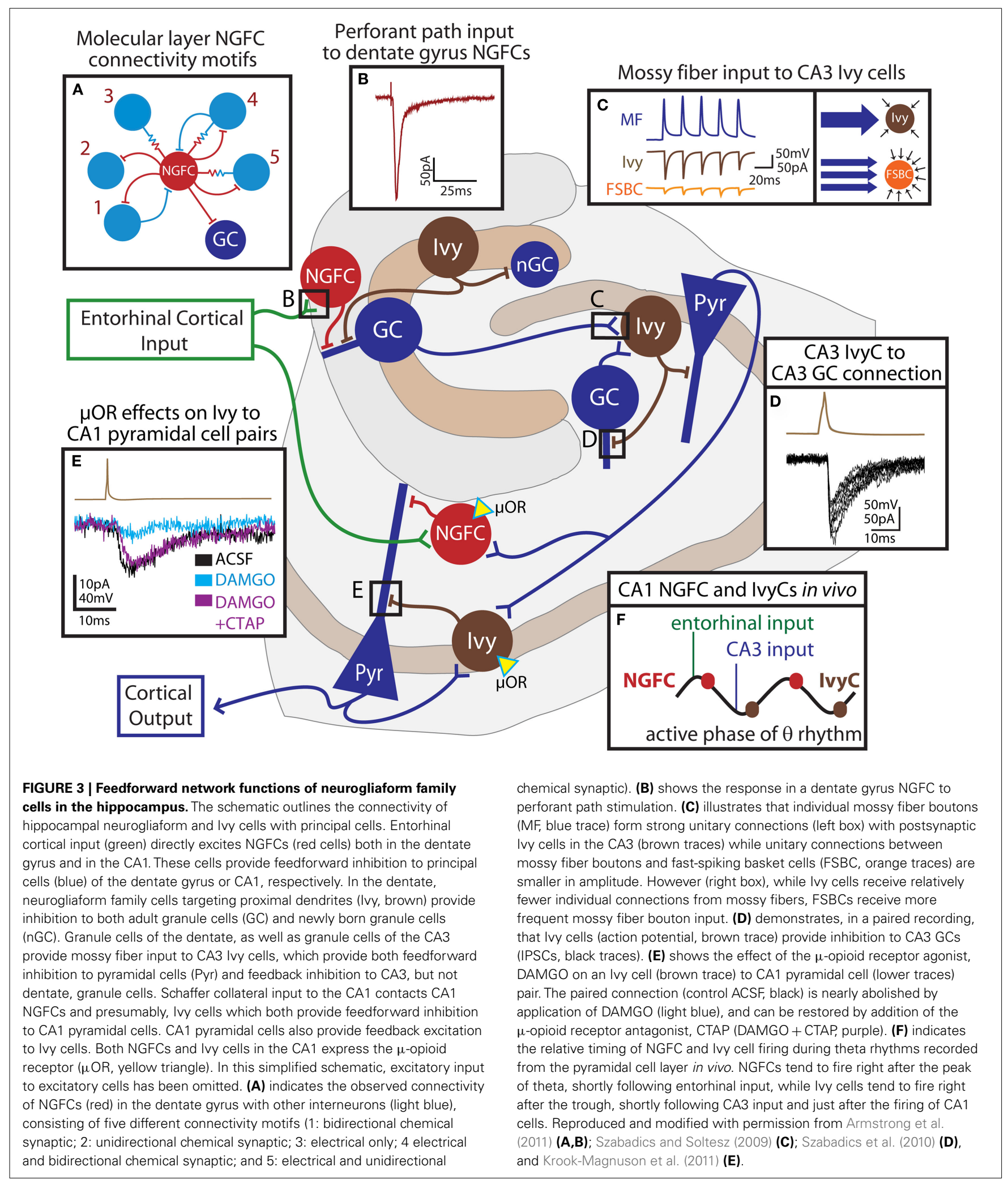

During this time period, there appears to be an integration of spiking information, eventually resulting in the induction of persistent firing. Once this state of persistent firing is achieved, spiking occurs without further input for tens of seconds (though in rare instances it can persist for over $10 \mathrm{~min}$; Sheffield et al., 2011). Persistent firing is not affected by blocking $\mathrm{GABA}_{\mathrm{A}}, \mathrm{GABA}_{\mathrm{B}}, \mathrm{AMPA}$, and NMDA 
receptors (Sheffield et al., 2011), but induction is inhibited by activation of $\mu$-opioid receptors (Krook-Magnuson et al., 2011). The apparent threshold for firing during persistent firing is very low when recording from the soma, and it has been shown that this is due to the action potentials starting in the axons themselves and back-propagating to the soma (Sheffield et al., 2011). Somatically recorded spikes have an initial component, representing spiking in the axon, and a subsequent component, indicative of a somatodendritic spike (Sheffield et al., 2011). The mechanism permitting the integration of spiking information over the span of minutes, required for the induction of persistent firing, is a matter of open debate and investigation, as are the physiological consequences of persistent firing. Importantly, however, not all interneurons display persistent firing (Krook-Magnuson et al., 2011; Sheffield et al., 2011). Indeed, less than $20 \%$ of fast-spiking parvalbumin expressing basket cells display persistent firing, in contrast to over $80 \%$ of neurogliaform family cells (Krook-Magnuson et al., 2011).

\section{NETWORK AND FUNCTIONAL ROLES OF NEUROGLIAFORM AND IVY CELLS}

Neurogliaform family cells have recently been described in the dentate gyrus (Armstrong et al., 2011; Markwardt et al., 2011). Neurogliaform cells located in the middle and outer molecular layers receive entorhinal input and synapse on distal dendrites of granule cells, meaning that they are capable of providing feedforward inhibition (Armstrong et al., 2011; Figures 1 and 3). Compared to granule cells, neurogliaform cells in the dentate molecular layer receive fewer spontaneous inputs (consisting of excitatory and inhibitory events at roughly equal frequencies) to their small dendritic arbors than granule cells. However, like granule cells, they do receive direct perforant path input from the entorhinal cortex. This perforant path input is facilitating at high frequencies, and suggests that neurogliaform cells may act to inhibit granule cells primarily during high frequency incoming activity (Armstrong et al., 2011).

In regions like the dentate gyrus, where granule cells exhibit sparse firing, feedforward GABAergic input has been predicted to play a major role in normal function (Ferrante et al., 2009), including for spatial navigation, as well as in pathological states, such as in epilepsy. Because neurogliaform cells target the distal dendrites of principal cells, they may have stronger effects on the processing of incoming input in dendritic compartments than on spike timing control per se. However, inhibitory dendritic input, in addition to its role in dendritic processing, has also recently been shown to have major effects on the firing of postsynaptic cells (Lovett-Barron et al., 2012). Thus, new studies will be necessary to determine what the major effect of neurogliaform cell activation may be during concurrent dendritic input to granule cells from other sources.

The fact that neurogliaform cells form both chemical and electrical synapses with other classes of GABAergic neurons means that they can display a variety of connectivity motifs. In the dentate gyrus molecular layer, for example, every possible twocell connectivity motif between neurogliaform cells and other types of interneurons was observed (electrical only, unidirectional synaptic, bidirectional synaptic, and combinations of electrical and synaptic connections; Armstrong et al., 2011; Figure 3). The microcircuit functions of neurogliaform family cells in this context remain to be determined. This arrangement could serve a number of important roles in the network, possibly synchronizing neuronal subgroups, inhibiting nearby neuronal subgroups, or acting as low-pass filters on incoming input to distinct cell types (Mitchell and Silver, 2003; Zsiros et al., 2007). Computational studies will help to determine the significance of this connectivity for overall network function (Santhakumar et al., 2005; DyhrfjeldJohnsen et al., 2007; Morgan and Soltesz, 2008; Ferrante et al., 2009; Cutsuridis and Hasselmo, 2012).

In the dentate, where neurogenesis of granule cells occurs throughout life, cells of the neurogliaform family play another important role, being among the first sources of input to newly born granule cells (Markwardt et al., 2011). Dentate neurogliaform family cells not only inhibit adult granule cells directly, but also inhibit other interneurons (indeed, burst firing in neurogliaform family cells during $4 \mathrm{AP}$ application coincided with robust suppression of spontaneous firing of other interneuronal types) and may therefore also disinhibit mature cells (Markwardt et al., 2011). In this way, neurogliaform family cells might coordinate activity of both newly born and adult granule cells, via direct depolarization of newborn granule cells (through depolarizing GABA effects) and coincident disinhibition of mature cells (Markwardt et al., 2011). The advent of novel ways to probe the roles of specific neuronal subgroups in vivo, such as optogenetic methods, provide ways of investigating how neurogliaform family cells may enhance or direct the integration of newly born cells into the network, and to better understand under what conditions neurogliaform cells have a predominately inhibitory action on adult granule cells (e.g., feedforward inhibition), and under what conditions neurogliaform cells produce a net disinhibition of granule cells (by inhibiting other interneurons).

Just as neurogliaform cells can mediate feedforward inhibition to dentate granule cells, Ivy cells in the CA3 region are similarly positioned to mediate feedforward inhibition to CA3 pyramidal cells (Szabadics and Soltesz, 2009). In paired recordings between mossy fiber boutons of granule cells and postsynaptic CA3 interneurons, Ivy cells received fewer, but stronger unitary connections from mossy fibers than fast-spiking basket cells (Szabadics and Soltesz, 2009). This arrangement suggests that individual large amplitude inputs from individual mossy fibers to Ivy cells may be capable of inducing feedforward inhibition to CA3 pyramidal cells, while other interneurons, such as fast-spiking basket cells, require greater convergent input from a number of mossy fiber terminals in order to produce feedforward inhibition. Interestingly, granule cells have recently been identified within the CA3, where their excitatory inputs from entorhinal cortex and mossy fiber outputs to both glutamatergic and GABAergic cells of the CA3, as well as their electrophysiological properties, are similar to those of granule cells located in the dentate (Szabadics et al., 2010). Unlike dentate granule cells, however, CA3 granule cells have reciprocal connections with CA3 Ivy cells, as well as with other GABAergic cells of the CA3 (Szabadics et al., 2010; Figure 3). Therefore, CA3 granule cells represent a unique, local glutamatergic neuronal subtype which in addition to both exciting CA3 pyramidal cells and GABAergic 
cells to drive feedforward inhibition, also receive feedback input from the CA3 GABAergic network. Ivy cells providing simultaneous feedforward inhibition to CA3 pyramidal cells and feedback inhibition of CA3 granule cells, may have important implications for oscillatory activity and spike timing within this brain region.

Finally, neurogliaform cells in CA1 are also positioned to mediate feedforward inhibition, as they receive input from both CA3 and entorhinal cortex, and in turn inhibit CA1 pyramidal cells (in addition to interneurons; Vida et al., 1998; Price et al., 2005; Price et al., 2008). Feedforward inhibition in CA1 can be very strong; following the stimulation of the temporoammonic pathway, a predominately inhibitory response is generated in CA1 pyramidal cells (Soltesz and Jones, 1995). Relevant to our discussion, this inhibitory response consists of both postsynaptic $\mathrm{GABA}_{\mathrm{A}}$ and $\mathrm{GABA}_{\mathrm{B}}$ components (Empson and Heinemann, 1995), which may implicate involvement of neurogliaform cells.

\section{NEUROMODULATORS AND NEUROGLIAFORM FAMILY CELLS}

Neuromodulatory influences onto and arising from neurogliaform family cells are only beginning to be uncovered. One recent interesting finding involves the effects of opioids on these cells in the CA1. In studies of input to CA1 from CA3 and entorhinal cortex, it was noted that stimulating the temporo-ammonic pathway one theta cycle before stimulating Schaffer collateral input leads to inhibition of the second excitatory input to CA1 pyramidal cells in a $\mathrm{GABA}_{\mathrm{B}}$-dependent, opioid-sensitive manner (Dvorak-Carbone and Schuman, 1999; McQuiston, 2011). In the context of the known properties of neurogliaform family cells, this observation suggests that neurogliaform cells could be modulated by opioids. In fact, both Ivy and neurogliaform cells were recently found to be highly modulated by $\mu$-opioid receptors (Krook-Magnuson et al., 2011). Activation of $\mu$-opioid receptors produced both somatic hyperpolarization and inhibition of neurotransmitter release from terminals. Indeed, in paired recordings between Ivy and pyramidal cells, activation of $\mu$-opioid receptors nearly abolished the Ivy cell-mediated inhibitory postsynaptic current (IPSC; Figure 3). Together these findings and others suggest not only that neurogliaform cells can mediate feedforward inhibition, and that feedforward inhibition interacts with the timing of impinging excitatory inputs to CA1 pyramidal cells, but also that this inhibition is highly modulated by opioids. This has implications both for understanding the mechanisms of action of drugs of abuse that act at the $\mu$-opioid receptor (such as heroin), as well as for the physiological function of CA1 during exploration, learning, and memory. Indeed, $\mu$-opioid receptor knock-out mice show reduced radial-arm maze and Morris water maze performance (Jamot et al., 2003). Further, alterations in the hippocampal opioid system are also seen, for example, in epilepsy and Alzheimer's, indicating a potential role in these disorders (Laorden et al., 1985; Gall, 1988; Gall et al., 1988; D'Intino et al., 2006; Rocha et al., 2007; Cuellar-Herrera et al., 2012). Moreover, in a model of Alzheimer's it was found that the reported increase in enkephalin (an endogenous ligand for $\mu$-opioid receptors) contributed to the cognitive difficulties associated with the disease (Meilandt et al., 2008), indicating that changes in the hippocampal opioid system can have significant functional consequences.

In addition to new insights into the neuromodulation of neurogliaform family output, the expression of such neuroactive markers as NPY and nNOS suggests that neurogliaform family cells may be important sources of both NPY and NO in the brain. NPY is a neuropeptide with a range of reported functions, including stimulating dentate neurogenesis (Howell et al., 2007). Additionally, NPY is implicated in anxiolysis, in the mechanisms of antidepressants (reviewed in Heilig, 2004), and in response to stress-veterans exposed to traumatic experiences but who had higher plasma levels of NPY experienced fewer stressrelated sequelae such as post-traumatic stress disorder (PTSD) and depression than those with lower NPY levels (Morgan et al., 2002; Yehuda et al., 2006). Interestingly, NPY may also be important in epilepsy; both the level of NPY protein and its receptor subtypes are robustly changed after seizures, and NPY overexpression is protective against acute and chronic seizures. This suggests that neurogliaform family cells may be important in suppressing seizure activity in epilepsy (Vezzani et al., 1999; Bacci et al., 2002; Noè et al., 2008; Noe et al., 2010; Kovac et al., 2011).

The expression of nNOS by cells of the neurogliaform family is especially interesting since it is not yet known how the interneuronal production of NO may contribute to overall network activity. While the known functions of NO in neuronal and non-neuronal tissues are numerous, the roles of nNOS and NO in specific GABAergic cell types, such as neurogliaform family cells, has yet to be determined. However, NO is a well-known retrograde modulator, and nNOS in neurogliaform cells may therefore involve synapse- and cell type-specific regulation of transmission from both excitatory and inhibitory inputs. This may serve to modulate levels of neurogliaform activity (and thus levels of GABAergic volume transmission) during specific input patterns (Szabadits et al., 2007; Feil and Kleppisch, 2008; Maggesissi et al., 2009; Zanelli et al., 2009; Szabadits et al., 2011), or to affect long term synaptic plasticity (Shin and Linden, 2005; Anwyl, 2006; Lange et al., 2012). In addition, the known vasodilatory role of $\mathrm{NO}$ in the peripheral circulatory system and in the CNS (Hall and Behbehani, 1998; Cauli et al., 2004; Corsani et al., 2008; Melikian et al., 2009) suggests the possibility that neurogliaform family cells might play a major role in increasing perfusion to regions that are particularly active (Tamas et al., 2003; Simon et al., 2005). More studies are clearly needed to definitively address the role of nNOS in the function of neurogliaform family cells.

\section{SUMMARY AND OUTLOOK}

Neurogliaform family cells have unique intrinsic and synaptic properties and are found in a range of brain regions, including throughout the hippocampal formation. A number of roles for neurogliaform family cells have been proposed. In addition to functions related to their expression of NPY and nNOS, roles in influencing network synchrony and oscillatory activity have been proposed (Tamas et al., 2003; Simon et al., 2005; Zsiros et al., 2007; Fuentealba et al., 2008; Price et al., 2008; Olah et al., 2009; Karayannis et al., 2010). Their modulation by $\mu$-opioid receptors suggests that volume transmission by neurogliaform family cells may play 
a major role in the effects of opiates, and may be of importance for future pharmacological insights.

Interestingly, some GABAergic populations have been observed to select postsynaptic partners based on long-range projection patterns. For example, in the entorhinal cortex, CCK-positive basket cells selectively target only those principal cells which project to contralateral extrahippocampal structures, avoiding principal cells which project to the ipsilateral hippocampus and form the perforant path (Varga et al., 2010). In contrast, due to their unique volume neurotransmission, neurogliaform cells are likely to indiscriminately inhibit all cells with processes within their axonal arbors. Thus, neurogliaform cells may represent a GABAergic cell class which coordinates the activity, or level of activity, between neurons processing information destined for distinct brain regions (Krook-Magnuson et al., 2012). This idea is particularly interesting when considering that cells with different long-range projection patterns may intermingle within a single cell layer (Varga et al., 2010). Moreover, as neurogliaform cells have been found to cross boundaries (e.g., the hippocampal fissure), they may also directly regulate concurrent activity in distinct brain regions (Ceranik

\section{REFERENCES}

Anwyl, R. (2006). Induction and expression mechanisms of postsynaptic NMDA receptor-independent homosynaptic long-term depression. Prog. Neurobiol. 78, 17-37.

Armstrong, C., Szabadics, J., Tamas, G., and Soltesz, I. (2011). Neurogliaform cells in the molecular layer of the dentate gyrus as feed-forward gamma-aminobutyric acidergic modulators of entorhinalhippocampal interplay. J. Comp. Neurol. 519, 1476-1491.

Bacci, A., Huguenard, J. R., and Prince, D. A. (2002). Differential modulation of synaptic transmission by neuropeptide $\mathrm{Y}$ in rat neocortical neurons. Proc. Natl. Acad. Sci. U.S.A. 99, 17125-17130.

Buzsaki, G. (2002). Theta oscillations in the hippocampus. Neuron 33, 325-340.

Capogna, M., and Pearce, R. A. (2011). GABAA, slow: causes and consequences. Trends Neurosci. 34, 101-112.

Cauli, B., Tong, X.-K., Rancillac, A., Serluca, N., Lambolez, B., Rossier, J., and Hamel, E. (2004). Cortical GABA interneurons in neurovascular coupling: relays for subcortical vasoactive pathways. J. Neurosci. 24, 8940-8949.

Ceranik, K., Bender, R., Geiger, J. R., Monyer, H., Jonas, P., Frotscher, M., and Lubke, J. (1997). A novel type of GABAergic interneuron connecting the input and the output regions of the hippocampus. J. Neurosci. 17, 5380-5394.

Corsani, L., Bizzoco, E., Pedata, F., Gianfriddo, M., Faussone-Pellegrini, M.
S., and Vannucchi, M. G. (2008). Inducible nitric oxide synthase appears and is co-expressed with the neuronal isoform in interneurons of the rat hippocampus after transient ischemia induced by middle cerebral artery occlusion. Exp. Neurol. 211, 433-440.

Cuellar-Herrera, M., Velasco, A. L., Velasco, F., Chavez, L., OrozcoSuarez, S., Armagan, G., Turunc, E., Bojnik, E., Yalcin, A., Benyhe, S., Borsodi, A., Alonso-Vanegas, M., and Rocha, L. (2012). Mu opioid receptor mRNA expression, binding, and functional coupling to G-proteins in human epileptic hippocampus. Hippocampus 22, 122-127.

Cutsuridis, V., and Hasselmo, M. (2012). GABAergic contributions to gating, timing, and phase precession of hippocampal neuronal activity during theta oscillations. Hippocampus.

D’Intino, G., Vaccari, F., Sivilia, S., Scagliarini, A., Gandini, G., Giardino, L., and Calza, L. (2006). A molecular study of hippocampus in dogs with convulsion during canine distemper virus encephalitis. Brain Res. 1098, 186-195.

Deller, T., and Leranth, C. (1990). Synaptic connections of neuropeptide Y (NPY) immunoreactive neurons in the hilar area of the rat hippocampus. J. Comp. Neurol. 300, 433-447.

Dvorak-Carbone, H., and Schuman, E. M. (1999). Patterned activity in stratum lacunosum moleculare inhibits CA1 pyramidal neuron firing. $J$. Neurophysiol. 82, 3213-3222.

Dyhrfjeld-Johnsen, J., Santhakumar, V., Morgan, R. J., Huerta, R., Tsimring,

et al., 1997; Price et al., 2005; Fuentealba et al., 2010; Armstrong et al., 2011).

The role of neurogliaform family cells as important feedforward inhibitors is supported by in vitro and existing in vivo data, but the wide connectivity and unique properties of these cells with other interneurons complicates our understanding of their true network functions. Ultimately, more studies, including studies in vivo in awake, behaving animals are needed to determine how neurogliaform and Ivy cells behave in information processing and network activities during different behavioral states. A comprehensive understanding of the roles of these unique neurons and their peculiar connective properties promises to shed light on new mechanisms by which microcircuits interact within and across brain areas.

\section{ACKNOWLEDGMENTS}

This work was supported by the US National Institutes of Health grants NS35915, NS074702, and NS74432, the Epilepsy Foundation (to Caren Armstrong), and the George E. Hewitt Foundation for Medical Research (to Esther Krook-Magnuson).

L., and Soltesz, I. (2007). Topological determinants of epileptogenesis in large-scale structural and functional models of the dentate gyrus derived from experimental data. $J$. Neurophysiol. 97, 1566-1587.

Elfant, D., Pal, B. Z., Emptage, N., and Capogna, M. (2008). Specific inhibitory synapses shift the balance from feedforward to feedback inhibition of hippocampal CA1 pyramidal cells. Eur. J. Neurosci. 27, 104-113.

Empson, R. M., and Heinemann, U. (1995). The perforant path projection to hippocampal area CA1 in the rat hippocampal-entorhinal cortex combined slice. J. Physiol. (Lond.) 484(Pt 3), 707-720.

Feil, R., and Kleppisch, T. (2008) "NO/cGMP-dependent modulation of synaptic transmission," Pharmacology of Neurotransmitter Release, eds T. C. Südhof and K. Starke (Berlin: Springer), 529-560.

Ferrante, M., Migliore, M., and Ascoli, G. A. (2009). Feed-forward inhibition as a buffer of the neuronal input-output relation. Proc. Natl. Acad. Sci. U.S.A. 106, 18004-18009.

Fuentealba, P., Begum, R., Capogna, M., Jinno, S., Marton, L. F., Csicsvari, J., Thomson, A., Somogyi, P., and Klausberger, T. (2008). Ivy cells: a population of nitric-oxideproducing, slow-spiking GABAergic neurons and their involvement in hippocampal network activity. $\mathrm{Neu}$ ron 57, 917-929.

Fuentealba, P., Klausberger, T., Karayannis, T., Suen, W. Y., Huck, J., Tomioka, R., Rockland, K., Capogna, M.,
Studer, M., Morales, M., and Somogyi, P. (2010). Expression of COUPTFII nuclear receptor in restricted GABAergic neuronal populations in the adult rat hippocampus. J. Neurosci. 30, 1595-1609.

Gall, C. (1988). Seizures induce dramatic and distinctly different changes in enkephalin, dynorphin, and CCK immunoreactivities in mouse hippocampal mossy fibers. J. Neurosci. 8, 1852-1862.

Gall, C. M., Pico, R. M., and Lauterborn, J. C. (1988). Focal hippocampal lesions induce seizures and longlasting changes in mossy fiber enkephalin and CCK immunoreactivity. Peptides 9(Suppl. 1), 79-84.

Hall, C. W., and Behbehani, M. M. (1998). Synaptic effects of nitric oxide on enkephalinergic, GABAergic, and glutamatergic networks of the rat periaqueductal gray. Brain Res. 805, 69-87.

Heilig, M. (2004). The NPY system in stress, anxiety and depression. $\mathrm{Neu}$ ropeptides 38, 213-224.

Howell, O. W., Silva, S., Scharfman, H. E., Sosunov, A. A., Zaben, M., Shatya, A., Mckhann Ii, G., Herzog, H., Laskowski, A., and Gray, W. P. (2007). Neuropeptide Y is important for basal and seizure-induced precursor cell proliferation in the hippocampus. Neurobiol. Dis. 26, 174-188.

Ibanez-Sandoval, O., Tecuapetla, F., Unal, B., Shah, F., Koos, T., and Tepper, J. M. (2011). A novel functionally distinct subtype of striatal neuropeptide Y interneuron. J. Neurosci. 31, 16757-16769. 
Jamot, L., Matthes, H. W., Simonin, F., Kieffer, B. L., and Roder, J. C. (2003). Differential involvement of the mu and kappa opioid receptors in spatial learning. Genes Brain Behav. 2, 80-92.

Karagiannis, A., Gallopin, T., David, C., Battaglia, D., Geoffroy, H., Rossier, J., Hillman, E. M., Staiger, J. F., and Cauli, B. (2009). Classification of NPY-expressing neocortical interneurons. J. Neurosci. 29, 3642-3659.

Karayannis, T., Elfant, D., HueraOcampo, I., Teki, S., Scott, R. S., Rusakov, D. A., Jones, M. V., and Capogna, M. (2010). Slow GABA transient and receptor desensitization shape synaptic responses evoked by hippocampal neurogliaform cells. J. Neurosci. 30, 9898-9909.

Klausberger, T., and Somogyi, P. (2008). Neuronal diversity and temporal dynamics: the unity of hippocampal circuit operations. Science 321, 53-57.

Kovac, S., Megalogeni, M., and Walker, M. (2011). In vitro effects of neuropeptide $\mathrm{Y}$ in rat neocortical and hippocampal tissue. Neurosci. Lett. 492, 43-46.

Krook-Magnuson, E., and Huntsman, M. M. (2007). The transience of interneuron circuit diversity just "sped" up. Proc. Natl. Acad. Sci. U.S.A. 104, 16723-16724.

Krook-Magnuson, E., Luu, L., Lee, S. H., Varga, C., and Soltesz, I. (2011). Ivy and neurogliaform interneurons are a major target of mu-opioid receptor modulation. J. Neurosci. 31, 14861-14870.

Krook-Magnuson, E., Varga, C., Lee, S. H., and Soltesz, I. (2012). New dimensions of interneuronal specialization unmasked by principal cell heterogeneity. Trends Neurosci. 35, 175-184.

Lange, M. D., Doengi, M., Lesting, J., Pape, H. C., and Jüngling, K. (2012). Heterosynaptic long-term potentiation at interneuron-principal neuron synapses in the amygdala requires nitric oxide signalling. $J$. Physiol. (Lond.) 590, 131-143.

Laorden, M. L., Olaso, M. J., Miralles, F. S., and Puig, M. M. (1985). Cerebrospinal fluid leucine-enkephalinlike levels in febrile convulsions. Methods Find Exp. Clin. Pharmacol. 7, 75-77.

Lovett-Barron, M., Turi, G. F., Kaifosh, P., Lee, P. H., Bolze, F., Sun, X. H., Nicoud, J. F., Zemelman, B. V., Sternson, S. M., and Losonczy, A. (2012). Regulation of neuronal input transformations by tunable dendritic inhibition. Nat Neurosci. 15, 423-430.

Maggesissi, R. S., Gardino, P. F., Guimarães-Souza, E. M., Paes-DeCarvalho, R., Silva, R. B., and Calaza, K. C. (2009). Modulation of GABA release by nitric oxide in the chick retina: different effects of nitric oxide depending on the cell population. Vision Res. 49, 2494-2502.

Markwardt, S. J., Dieni, C. V., Wadiche, J. I., and Overstreet-Wadiche, L. (2011). Ivy/neurogliaform interneurons coordinate activity in the neurogenic niche. Nat. Neurosci. 14, 1407-1409.

McQuiston, A. R. (2011). Mu opioid receptor activation normalizes temporo-ammonic pathway driven inhibition in hippocampal CA1. Neuropharmacology 60, 472-479.

Meilandt, W. J., Yu, G. Q., Chin, J., Roberson, E. D., Palop, J. J., Wu, T., Scearce-Levie, K., and Mucke, L. (2008). Enkephalin elevations contribute to neuronal and behavioral impairments in a transgenic mouse model of Alzheimer's disease. J. Neurosci. 28, 5007-5017.

Melikian, N., Seddon, M. D., Casadei, B., Chowienczyk, P. J., and Shah, A. M. (2009). Neuronal nitric oxide synthase and human vascular regulation. Trends Cardiovasc. Med. 19, 256-262.

Mitchell, S. J., and Silver, R. A. (2003). Shunting inhibition modulates neuronal gain during synaptic excitation. Neuron 38, 433-445.

Mizuseki, K., Sirota, A., Pastalkova, E., and Buzsaki, G. (2009). Theta oscillations provide temporal windows for local circuit computation in the entorhinal-hippocampal loop. Neuron 64, 267-280.

Morgan Iii, C. A., Rasmusson, A. M., Wang, S., Hoyt, G., Hauger, R. L., and Hazlett, G. (2002). Neuropeptide$\mathrm{Y}$, cortisol, and subjective distress in humans exposed to acute stress: replication and extension of previous report. Biol. Psychiatry 52, 136-142.

Morgan, R. J., and Soltesz, I. (2008). Nonrandom connectivity of the epileptic dentate gyrus predicts a major role for neuronal hubs in seizures. Proc. Natl. Acad. Sci. U.S.A. 105, 6179-6184.

Noè, F., Pool, A.-H., Nissinen, J., Gobbi, M., Bland, R., Rizzi, M., Balducci, C., Ferraguti, F., Sperk, G., During, M. J., Pitkänen, A., and Vezzani, A. (2008). Neuropeptide Y gene therapy decreases chronic spontaneous seizures in a rat model of temporal lobe epilepsy. Brain 131, 1506-1515.
Noe, F., Vaghi, V., Balducci, C., Fitzsimons, H., Bland, R., Zardoni, D. Sperk, G., Carli, M., During, M. J., and Vezzani, A. (2010). Anticonvulsant effects and behavioural outcomes of rAAV serotype 1 vectormediated neuropeptide $\mathrm{Y}$ overexpression in rat hippocampus. Gene Ther. 17, 643-652.

Olah, S., Fule, M., Komlosi, G., Varga, C., Baldi, R., Barzo, P., and Tamas, G. (2009). Regulation of cortical microcircuits by unitary GABA-mediated volume transmission. Nature 461, 1278-1281.

Olah, S., Komlosi, G., Szabadics, J., Varga, C., Toth, E., Barzo, P., and Tamas, G. (2007). Output of neurogliaform cells to various neuron types in the human and rat cerebral cortex. Front. Neural Circuits 1:4. doi:10.3389/neuro.04.004.2007

Pearce, R. A. (1993). Physiological evidence for two distinct GABAA responses in rat hippocampus. $\mathrm{Neu}$ ron 10, 189-200.

Povysheva, N. V., Zaitsev, A. V., Kroner, S., Krimer, O. A., Rotaru, D. C., Gonzalez-Burgos, G., Lewis, D. A., and Krimer, L. S. (2007). Electrophysiological differences between neurogliaform cells from monkey and rat prefrontal cortex. J. Neurophysiol. 97, 1030-1039.

Price, C. J., Cauli, B., Kovacs, E. R., Kulik, A., Lambolez, B., Shigemoto, R., and Capogna, M. (2005). Neurogliaform neurons form a novel inhibitory network in the hippocampal CA1 area. J. Neurosci. 25 , 6775-6786.

Price, C. J., Scott, R., Rusakov, D. A., and Capogna, M. (2008). GABA(B) receptor modulation of feedforward inhibition through hippocampal neurogliaform cells. J. Neurosci. 28, 6974-6982.

Ramón y Cajal, S. (1922). Studien über die Sehrinde der Katze. J. Psychol. Neurol. 29, 161-181.

Ramón y Cajal, S. (1999). Texture of the Nervous System of Man and the Vertebrates. Barcelona: SpringVerlag/Wein Springer.

Ratzliff, A. D., and Soltesz, I. (2001). Differential immunoreactivity for alpha-actinin-2, an Nmethyl-D-aspartate-receptor/actin binding protein, in hippocampal interneurons. Neuroscience 103, 337-349.

Rocha, L., Cuellar-Herrera, M., Velasco, M., Velasco, F., Velasco, A. L., Jimenez, F., Orozco-Suarez, S., and Borsodi, A. (2007). Opioid receptor binding in parahippocampus of patients with temporal lobe epilepsy: its association with the antiepileptic effects of subacute electrical stimulation. Seizure 16, 645-652.

Santhakumar, V., Aradi, I., and Soltesz, I. (2005). Role of mossy fiber sprouting and mossy cell loss in hyperexcitability: a network model of the dentate gyrus incorporating cell types and axonal topography. J. Neurophysiol. 93, 437-453.

Sheffield, M. E., Best, T. K., Mensh, B. D., Kath, W. L., and Spruston, N. (2011). Slow integration leads to persistent action potential firing in distal axons of coupled interneurons. Nat. Neurosci. 14, 200-207.

Shin, J. H., and Linden, D. J. (2005). An NMDA receptor/nitric oxide cascade is involved in cerebellar LTD but is not localized to the parallel fiber terminal. J. Neurophysiol. 94 , 4281-4289.

Simon, A., Olah, S., Molnar, G., Szabadics, J., and Tamas, G. (2005). Gap-junctional coupling between neurogliaform cells and various interneuron types in the neocortex. J. Neurosci. 25, 6278-6285.

Soltesz, I., and Jones, R. S. (1995). The direct perforant path input to CA1: excitatory or inhibitory? Hippocampus 5, 101-103.

Suzuki, N., and Bekkers, J. M. (2012). Microcircuits mediating feedforward and feedback synaptic inhibition in the piriform cortex. $\mathrm{J}$. Neurosci. 32, 919-931.

Szabadics, J., and Soltesz, I. (2009). Functional specificity of mossy fiber innervation of GABAergic cells in the hippocampus. J. Neurosci. 29, 4239-4251.

Szabadics, J., Tamas, G., and Soltesz, I. (2007). Different transmitter transients underlie presynaptic cell type specificity of GABAA,slow and GABAA, fast. Proc. Natl. Acad. Sci. U.S.A. 104, 14831-14836.

Szabadics, J., Varga, C., Brunner, J., Chen, K., and Soltesz, I. (2010). Granule cells in the CA3 area. J. Neurosci. 30, 8296-8307.

Szabadits, E., Cserép, C., Ludányi, A., Katona, I., Gracia-Llanes, J., Freund, T. F., and Nyíri, G. (2007). Hippocampal GABAergic synapses possess the molecular machinery for retrograde nitric oxide signaling. $J$. Neurosci. 27, 8101-8111.

Szabadits, E., Cserép, C., Szonyi, A., Fukazawa, Y., Shigemoto, R., Watanabe, M., Itohara, S., Freund, T. F., and Nyiri, G. (2011). NMDA receptors in hippocampal GABAergic synapses and their role in nitric oxide signaling. J. Neurosci. 31, 5893-5904.

Tamas, G., Lorincz, A., Simon, A., and Szabadics, J. (2003). Identified 
sources and targets of slow inhibition in the neocortex. Science 299, 1902-1905.

Tricoire, L., Pelkey, K. A., Daw, M. I., Sousa, V. H., Miyoshi, G., Jeffries, B., Cauli, B., Fishell, G., and Mcbain, C. J. (2010). Common origins of hippocampal Ivy and nitric oxide synthase expressing neurogliaform cells. J. Neurosci. 30, 2165-2176.

Varga, C., Lee, S. Y., and Soltesz, I. (2010). Target-selective GABAergic control of entorhinal cortex output. Nat. Neurosci. 13, 822-824.

Vezzani, A., Sperk, G., and Colmers, W. F. (1999). Neuropeptide Y: emerging evidence for a functional role in seizure modulation. Trends Neurosci. $22,25-30$.

Vida, I., Halasy, K., Szinyei, C., Somogyi, P., and Buhl, E. H. (1998). Unitary IPSPs evoked by interneurons at the stratum radiatum-stratum lacunosum-moleculare border in the CAl area of the rat hippocampus in vitro. J. Physiol. (Lond.) 506(Pt 3), 755-773.

Weiss, T., and Veh, R. W. (2011). Morphological and electrophysiological characteristics of neurons within identified subnuclei of the lateral habenula in rat brain slices. Neuroscience 172, 74-93.

Yehuda, R., Brand, S., and Yang, R.K. (2006). Plasma neuropeptide Y concentrations in combat exposed veterans: relationship to trauma exposure, recovery from PTSD, and coping. Biol. Psychiatry 59, 660-663.

Zanelli, S., Naylor, M., and Kapur, J. (2009). Nitric oxide alters GABAergic synaptic transmission in cultured hippocampal neurons. Brain Res. 1297, 23-31.
Zsiros, V., Aradi, I., and Maccaferri, G. (2007). Propagation of postsynaptic currents and potentials via gap junctions in GABAergic networks of the rat hippocampus. J. Physiol. (Lond.) 578, 527-544.

Zsiros, V., and Maccaferri, G. (2005) Electrical coupling between interneurons with different excitable properties in the stratum lacunosum-moleculare of the juvenile CA1 rat hippocampus. $J$. Neurosci. 25, 8686-8695.

Zsiros, V., and Maccaferri, G. (2008). Noradrenergic modulation of electrical coupling in GABAergic networks of the hippocampus. J. Neurosci. 28, 1804-1815.

Conflict of Interest Statement: The authors declare that the research was conducted in the absence of any commercial or financial relationships that could be construed as a potential conflict of interest.

Received: 29 February 2012; paper pending published: 22 March 2012; accepted: 13 April 2012; published online: 16 May 2012.

Citation: Armstrong C, KrookMagnuson E and Soltesz I (2012) Neurogliaform and Ivy cells: a major family of $n N O S$ expressing GABAergic neurons. Front. Neural Circuits 6:23. doi: 10.3389/fncir.2012.00023

Copyright (c) 2012 Armstrong, KrookMagnuson and Soltesz. This is an openaccess article distributed under the terms of the Creative Commons Attribution Non Commercial License, which permits non-commercial use, distribution and reproduction in other forums, provided the original authors and source are credited. 